\title{
EGFR NM_005228.3:c.2311_2312ins9
}

National Cancer Institute

\section{Source}

National Cancer Institute. EGFR NM 005228.3:C.2311 2312ins9. NCI Thesaurus. Code C98659.

An insertion of nine nucleotides, GCGT GGACA, between position 2311 and 2312 of the coding sequence of the EGFR gene. 